DOI: 10.46340/eppd.2020.7.2.33

Олексій Юлдашев, д. ю. н.

Олена Міхатуліна, д. філос. в галузі права

Міжрегіональна академія управління персоналом, Україна

Поліна Юлдашева

Навчально-консультативний центр «Квеста консальтинг», Україна

ІННОВАЦІЙНЕ НАВЧАННЯ

В УМОВАХ УНІВЕРСИТЕТСЬКОЇ

АВТОНОМIÏ

Oleksii Yuldashev, ScD in Law
ORCID ID: https://orcid.org/0000-0002-6624-3481
Interregional Academy of Personnel Management, Ukraine

Olena Mikhatulina, PhD in Law

ORCID ID: https://orcid.org/0000-0002-77124-3742

Interregional Academy of Personnel Management, Ukraine

Polina Yuldasheva

ORCID ID: https://orcid.org/0000-0002-7781-2635

Training and Consulting Center "Questa Consulting", Ukraine

\title{
INNOVATIVE STUDYING IN CONDITIONS OF UNIVERSITY AUTONOMY
}

It is proved that the quality of education is determined by the quality of the educational process, the content of educational disciplines. The productivity of the content of the discipline depends entirely on the degree, level of saturation with the latest novels most useful for the future specialist. This level should be assessed by the proportion of the latest knowledge. Such knowledge (newest provisions, innovations) can be obtained from the results of science, scientific research. These results should be included in the courses, defining their content. The concept of innovative training and quality management of the educational process is offered. The proposed set of ideas can be considered as a means of improving the quality of education, as a possible alternative to solving the most important state problem - the progressive economic and technological backwardness of Ukraine in the field of innovation from the highly developed countries.

Keywords: innovative training, quality of education, educational standards, concept of innovative training, innovations in education, content of educational disciplines.

Постановка проблеми. Освіта посідає важливе місце у державній політиці України і потребує особливої уваги. Адже сучасний розвиток суспільства у напрямі демократії, вільної ринкової економіки не тільки може залишити осторонь освіту, а й зобов'язує її стати потужною рушійною силою відповідних перетворень. А для цього, потрібні не тільки модернізація освіти, інтеграція іiі в європейський та світовий простір, а й нові підходи до процесу навчання, яке будуються на сучасних засобах інформатизації, спрямовані на побудову суспільства знань.

Аналіз останніх досліджень і публікацій (Literature review). Програмні завдання в сфері освітньої політики та шляхи їх реалізації висвітлені працях В. Андрущенка, В. Журавського, І. Зязюна, О.Клименко, С. Квіта, К. Корсака, В.Кременя, О. Кузнєцова, К. Левківського, В. Лутая, Г. Михайлюка, М. Поповича, В.Ярошовця та інших.

Виділення невирішених раніше частин загальної проблеми. Як засвідчує аналіз робіт названих авторів та ін. вчених, на сучасному етапі розвитку українського суспільства, переходу країни до інноваційної економіки, інформатизації суспільства - постає проблема використання 
освіти, вищої освіти як дієвого засобу досягнення цих цілей, соціального розвитку. Досліджуючи ці питання, багато які вчені обмежуються визначенням тих чи інших понять, класифікацій, принципів, іменуючи одержані результати теорією, методологією. Якщо це так, то можна казати про голод на розробки методичного рівня, які визначали б «ЩО» і, головне «ЯК» робити. Саме концептуальні положення здійснення певної діяльності (в даному випадку, освітньої) мають містити відповіді на зазначені питання. На основі цих відповідей і повинна грунтуватися розбудова державної освітньої політики, яка може бути визначена як форма, а самі концептуальні положення інтерпретуватися як зміст освітньої діяльності. Саме у симбіозі таких змісту та форми і могло б полягати «поєднання форми і змісту освітньої політики», здійснення «ефективного перерозподілу функцій і повноважень між центральними органами державної влади та навчальними закладами». А це те, що вимагає Національна доктрина розвитку освіти України у XXI столітті, ідея університетської автономії, закладена у Законі про вищу освіту від 1 липня 2014 року.

Мета статті. Метою статті є розробка концепції (сукупності основоположних ідей), достатньої для створення інноваційної (унікальної) моделі управління якістю навчального процесу в закладах вищої освіти, матеріально-енергетичне уречевлення якої призведе до прориву в переході до інформаційного суспільства, суспільства знань.

Виклад основного матеріалу. Загальновизнано, що саме інформація та знання стають домінантами в житті сучасного суспільства, головними продуктами суспільного виробництва. Входження людства в інформаційне суспільство та суспільство знань, пише Н. І. Гендіна,пред'являє якісно нові вимоги до системи освіти. Ці вимоги вилилися в необхідність зміни парадигми цієї системи. Модель «підтримуючого навчання», заснована на фіксованих, стійких прийомах $\mathrm{i}$ методах, які спрямовані на те, щоб навчитися працювати у традиційних постійно існуючих умовах неприйнятна для сучасного суспільства, відмінними рисами якого стали постійні зміни і зростаючий темп життя ${ }^{1}$.

Аналіз практики, політико-правових рішень і наукової літератури показує, що в якості головного засобу переходу до інформаційного суспільства найчастіше називається наука, розвиток науки. Набагато рідше говорять про освіту. Ще менше тих, хто говорить про спільну дію обох чинників як складових засобів цього переходу, що мають бути взаємопов'язаними, взаємообумовленими. Тобто, наука та освіта поки що розглядаються окремо один від одного. Одні чиновники-«реформатори» реформують освіту, а зовсім інші - переймаються змінами в науці. При цьому, дивлячись на висновки, пропозиції, рекомендації, які надходять від одних та других, нерідко складається враження, що перші і не підозрюють про існування других. Разом з тим, і наука та освіта, на наше глибоке переконання, є сторонами єдиного процесу, процесу інноваційного розвитку.

Про те, що головним орієнтиром вдосконалення освіти, навчального процесу у них став курс на залучення в процес навчання наукових результатів засвідчив і аналіз наявного європейського досвіду функціонування університетів. Це дійсно чи не єдиний шлях забезпечення інноваційності освіти, спрямованості іiі на створення інформаційного суспільства, суспільства знань. Проблеми викладання навчальних дисциплін (НД) саме під таким кутом активно обговорюються, принаймні, в останні 15-20 років в рамках так зв. Болонського процесу.

В Україні, як відомо, згідно із Законом України «Про вищу освіту», створено Національне агентство із забезпечення якості вищої освіти, як один з органів управління у цій сфері. Агентство $\epsilon$ постійно діючим колегіальним органом, уповноваженим на реалізацію державної політики у сфері забезпечення якості вищої освіти.

Серед найважливіших завдань Нацагентства - формування вимог до системи забезпечення якості вищої освіти, критеріїв оцінки якості освітньої діяльності, у тому числі наукових здобутків, за якими мають визначатися рейтинги вищих навчальних закладів вищої освіти України; проведення акредитації освітніх програм, розробка вимог до рівня наукової кваліфікації осіб, які здобувають наукові ступені тощо.

Розроблено і представлено Стратегію Національного агентства із забезпечення якості вищої освіти до 2022 р. Визначено місію і стратегічні цілі та загальні напрями їх реалізації. Місія Національного агентства із забезпечення якості вищої освіти - стати каталізатором позитивних змін у вищій освіті та формування культури її якості. Щодо стратегічних цілей, то вони реалізуються

${ }^{1}$ Гендина, Н.И., Колкова, Н.И., Скипор, И.Л., Стародубова, Г.А. (2003). Формирование информаичонной культуры личности в библиотеках и образовательных учреждениях: учебно-методическое пособие. 2-е изд., перераб. Москва: Школьная б-ка. 
за трьома головними напрямами: якість освітніх послуг, гарантування якості освітніх програм через впровадження ефективної процедури їх акредитації та вимогливого ставлення до процедур Агентства та діяльності закладів вищої освіти, сприяння функціонуванню внутрішніх систем забезпечення якості освіти у закладах вищої освіти, а також погодження стандартів та розробка критеріїв забезпечення якості вищої освіти на основі передових світових і національних практик.

Певні зусилля з реформування освіти формуються i в рамках недержавного сектору, громадських організаціях. До таких документів належить Дорожня карта реформування вищої освіти України, опублікована у березні 2018 р. ${ }^{1}$ Центральна ідея документу «Якість української вищої освіти залежить від реалізації концепції університетської автономії». Цей документ було створено в рамках проекту ElibUkr "Сприяння реформам у вищій освіті України з погляду розвитку академічної доброчесності", підтриманого Міжнародним благодійним фондом "Відродження". Якість української вищої освіти, зокрема, в частині забезпечення доброчесності, залежить, вважають автори документу, від реалізації концепції університетської автономії, що також спрямована на зміцнення громадянського суспільства і розвиток української академічної культури.

Закінчуючи огляд офіційних заходів, які приймає влада та розробляє громадськість 3 метою забезпечення якості освіти у закладах вишах, відмітимо, що Президент України підписав Закон «Про внесення змін до деяких законів України щодо вдосконалення освітньої діяльності у сфері вищої освіти“ № 392-IX, ухвалений Верховною Радою України 18 грудня 2019 року». Законопроект має на меті врегулювання процедури ліцензування освітньої діяльності, вступу на навчання для здобуття вищої освіти, реалізації міждисциплінарних освітніх програм. Документ урегульовує питання, що стосуються забезпечення якості вищої освіти, форм здобуття освіти, вимог до керівників закладів вищої освіти, Національної рамки кваліфікацій тощо. Закон, як випливає з намірів його авторів, створює умови для зміцнення європейських засад функціонування системи вищої освіти, що сприятиме іiі зближенню із системами інших країн Болонського процесу, а також збільшенню прозорості, доброчесності, автономії, відповідальності головних учасників освітнього процесу за результат. Передбачено також створення передумов для більш рівного доступу до освіти та якісного вимірювання результатів навчання завдяки розширенню сфери використання зовнішнього незалежного оцінювання.

Розроблено «Концепцію всебічної університетської автономії», ідея якої закладена в закон "Про вищу освіту". Отже, багато благих намірів, багато організаційної діяльності, особливо, пов'язаної з різноманітними формами контролю. А чи підвищився у закладах вищої освіти рівень їі якості? Чи підвищився статус українських ЗВО у міжнародних рейтингах? На жаль, позитивної відповіді на ці питання надати навряд чи можливо.

Характеризуючи у цілому роботу, що провадиться в Україні в цьому напрямку, ми також не можемо зробити висновок про достатність зроблених зусиль щодо забезпечення інноваційності освіти, спрямованості на створення інформаційного суспільства, суспільства знань.

Результати соціологічних опитувань роботодавців, випускників і студентів, інших учасників навчального процесу (стейкхолдерів), щодо якості випускників ЗВО, проведених соціологічними службами, а також і авторами цього дослідження, показує, що низький рівень працевлаштування молодих фахівців інженерно-технічних спеціальностей пов'язаний з низкою як об'єктивних i суб'єктивних причин. Серед них - саме низька якість практичної підготовки фахівців, невідповідність компетенцій випускників вимогам роботодавця, відсутність чітких професійних орієнтацій, інформаційних, особистісних ресурсів тощо.

Опитування роботодавців свідчить про зниження якості освітньої кваліфікації випускників, що, в свою чергу, говорить про зниження якості вищої освіти, невідповідності результатів навчання потребам суспільства. I це при тому, що компетентності випускників, оцінювані роботодавцями, визнані (посвідчується відповідними дипломами) такими, що відповідають вимогам законодавства та стандартам вищої освіти. За законом про вищу освіту ця відповідність підтверджується результатами внутрішнього та зовнішнього контролю якості вищої освіти.

Вважаємо, що таке положення склалося у зв'язку з відсутністю у складі об'єктів контролю, управління освітою та правової регламентації такого важливого ії компоненту як відповідність змісту навчальних дисциплін сучасним досягненням науки; не контролюється процес наповнення зазначеного змісту інформацією про найсучасніші досягнення в сфері науки і техніки. Саме тому

${ }^{1}$ Дорожня карта реформування вищої освіти України (2018). <dt.ua > EDUCATION > dorozhnya-karta-ref>. 
правове регулювання, присвячене регламентації вимог до навчального процесу, контролю за його здійсненням тощо, в т.ч. і чинний закон про вищу освіту у відповідній своїй частині, є, по суті, бюрократичним.

Ситуацію можна змінити шляхом введення нових вимог до змісту і якості освіти. Зміст освіти, в умовах переходу до інноваційної економіки, інформаційного суспільства має визначатися, виходячи з головної сьогодні функції освіти - залучати студентів до найсучасніших досягнень науки у відповідній галузі знань. Звідси випливає головна ідея, яку ми хочемо запропонувати: наситити навчальні програми, навчальні дисципліни найновішими і найкориснішими для майбутнього фахівця новелами, виходячи з результатів науки, наукових досліджень.

I це не повинно бути справою окремого вузу - насищати чи не насищати. Дане питання не можна віддавати на відкуп університетам, викладачам (а саме така, на жаль, позиція і українського, і європейського законодавства за вищезгаданим Болонським процесом). Недоречні, в цьому плані, i посилання на академічну автономію.

Результати усунення суб'єкта управління освітою (МОН, НАЗЯВО) від методичного управління змістом НД і контролю за ним- вочевидь. Адже людина, в силу своєї егоїстичної природи, мінімізація з боку викладача власних зусиль при роботі зі змістом НД. Людина, за своєю природою, завжди намагається зробити якомога менше того, що від неї вимагають. Якщо не вимагатимуть - то не робитися взагалі нічого. Звідси і використання деякими викладачами конспектів багаторічної давнини. Як пише Інна Совсун (першому екс замміністра Міністерства освіти і науки України не можна не вірити), багато викладачів роками (а то й десятиліттями) читають одні й ті ж курси, не застосовують сучасної літератури, не знайомі з сучасними технологіями. Говорячи про складність даної проблеми, автор додає: «На жаль, ці проблеми є, і змінити поведінку тисяч викладачів, змусити їх викладати інакше - дуже складно» ${ }^{1}$.

Складно, але можливо. Потрібно контролювати зміст навчальних дисциплін. Управляти його розробкою. I не тільки адміністративно. Перш за все, за допомогою методичного забезпечення насичення змісту навчальної дисципліни новітніми положеннями, відомостями про інновації. Основну роль у розробці такого забезпечення мають відіграти Науково-методична рада, а також науково-методичні комісії, що розробляють стандарти освітньої діяльності та стандарти вищої освіти. Автори готові надати проекти відповідних методичних матеріалів.

Однією з ідей з насичення змісту навчальної дисципліни новітніми науковими положеннями дисертацій, результатами НДР, наукових статей, є ідея про обов'язкове включення відповідних положень до згаданого змісту дисципліни. Можна запропонувати відповідні критерії, показники ступеню такого насичення. Пропонуємо ввести коефіцієнт насичення змісту навчальної дисципліни новітніми науковими положеннями дисертацій, результатами НДР, висновками наукових статей і т.д. Цей коефіцієнт чисто формально міг би визначатися як кількість імплементованих у навчальну дисципліну новел, до їх загальної кількості, що міститься у відповідних джерелах, у автоматизованому банку знань (АБЗ), який міг би бути створений i вестися за допомогою автоматизованих технологій. Безумовно, що відбір нових положень має здійснюватися викладачем його роль ніяк не принижується, а навпаки, зростає. Він, а також університет - відповідальні за зміст навчальної дисципліни. Саме за допомогою включення новітніх наукових положень має формуватися iї зміст. Студент, складаючи свій індивідуальний навчальний план (а такий план, як відомо, зараз $є$ обов'язковим для виконання здобувачем вищої освіти) діяв би вже не навмання, а більш свідомо, цілеспрямовано, більш зацікавлено, оскільки він мав би справу вже не з застарілою тематикою занять, а 3 конкретними новелами, які можуть викликати інтерес.

Зрозуміло, що потрібен механізм для такого роду імплементації, який би охоплював наступні функції: потрапляння наукових результатів у АБЗ, їх накопичення, систематизацію та доступ до інформації. Безумовно, що у АБЗ мала б накопичуватися не тільки інформація 3 наукових бібліотек, а й з відповідних патентних органів. Зрозуміло і те, що з метою забезпечення максимально зручного накопичення, систематизації та пошуку результатів дослідної роботи, вимоги до самих досліджень, їх проведення та викладення повинні бути змінені. Але це вже будуть вимоги для дисертацій не для збільшення корупційних ризиків, а для підвищення якості досліджень. Зазначимо, що сам факт обов’язкового потрапляння результатів дисертаційних і інших наукових досліджень,

${ }^{1}$ Ніколаєв, С.Б. (2017). Вища освіта в Україні: порядок денний для реформ. $<$ http://www.kas.de/wf/doc/kas_49177-1522-13-30.pdf?170612141803>. 
наукових статей до загального оприлюднення, до кінцевих споживачів наукових результатів - вже сам по собі буде стимулювати авторів до підвищення якості одержаних результатів. Адже дехто зі здобувачів наукового ступеню, в т.ч. і в галузі гуманітарних наук, намагається захиститись за закритою тематикою, прагнуть грифу секретності, незважаючи на те, що об'єкт дослідження явно не секретний. Особливо дивно це виглядає у соціально-гуманітарних сферах. Чому і там прагнуть до утаємниченості, намагаються приховати наукові результати від громадськості - залишається лише здогадуватися. Хоча здогадатися не важко. Все пов’язано з якістю науково-дослідної роботи.

Викладенню наших пропозицій щодо вимог до проведення досліджень, оцінки (критерії оцінки) наукових робіт та ін. буде присвячено самостійне дослідження. Зараз лише зазначимо, що наука, не маючи стійких зв'язків зі споживачами ії результатів, може також скотитися до повного формалізму, який проявляється, зокрема, у дослідженні так званих псевдопроблем ( «ще" не проблем, «вже" не проблем і «ніколи" не проблем). Це робота на себе, а не для зовнішнього споживача. Він ніби зникає. В результаті система (у нашому випадку - наука), бюрократизується. А тому важливо неформальне виконання вимог щодо зв'язку теми дослідження з практично значущими завданнями, а також оцінки одержаних результатів щодо їх користувачів. В якості такої тематики могли б бути використані завдання, що містяться у затверджених Кабінетом Міністрів пріоритетних тематичних напрямах наукових досліджень і науково-технічних розробок, державних цільових програмах.

Висновки і перспективи подальших розвідок у цьому напрямку. Якість освіти визначається якістю навчального процесу, а вона (якість навчання), обумовлюється змістом навчальних дисциплін. В свою чергу, продуктивність останнього (змісту дисципліни) цілковито залежить від ступеню, рівня насиченості його найновішими і найкориснішими для майбутнього фахівця новелами. Цей рівень повинен оцінюватися, перш за все, питомою вагою найновітніших знань. Одержати такі знання (новітні положення, інновації) можна з результатів науки, наукових досліджень. Ці результати повинні обов'язково включатися до навчальних дисциплін, визначаючи їх зміст. І це не слід віддавати на відкуп університетам, викладачам (а саме така, на жаль, позиція і українського, і європейського законодавства за проаналізованим вище Болонським процесом).

Запропоновано концепцію інноваційного навчання та управління якістю навчального процесу. Концепція може слугувати основою, достатньою для створення інноваційної (унікальної) моделі управління якістю навчального процесу в закладах вищої освіти, матеріально-енергетичне уречевлення якої призведе до прориву в переході до інформаційного суспільства, суспільства знань. Концепція є відзивом на виклики сучасного етапу розвитку інформатизації суспільства, переходу країни до інноваційної економіки. Запропонована сукупність ідей може розглядатися як засіб підвищення якості освіти, як можлива альтернатива вирішення найважливішої державної проблеми прогресуючого економічного і технологічного відставання України в області інновацій від високорозвинених держав

Концепція орієнтована, перш за все, на ЗВО економічних та інженерних спеціальностей, в т.ч. геології. Вона спрямована на набуття інноваційних знань, фіксує увагу саме на виробленні у майбутніх фахівців творчих здібностей, вмінь знаходити потрібну інформацію, аналізувати іiі, виявляти проблеми та визначати шляхи їх вирішення. А саме така якість фахівців, які здатні самостійно ставити цілі, забезпечувати їх досягнення - стає єдино можливою альтернативою для інноваційного розвитку країни, а отже і виживання, самозбереження нації як такої.

Нами розроблені організаційні механізми впровадження Концепції, але це тема окремого розгляду.

\section{References:}

1. Gendina, N.I., Kolkova, N.I., Skipor, I.L., Starodubova, G.A. (2003). Formirovanie informacionnoj kul'tury lichnosti v bibliotekah i obrazovatel'nyh uchrezhdenijah: uchebno-metodicheskoe posobie. 2-e izd., pererab. [The formation of the information culture of a person in libraries and educational institutions: a teaching tool. 2nd ed., Revised.]. Moscow: Shkol'naja b-ka. [in Russian].

2. Dorozhnia karta reformuvannia vyshchoi osvity Ukrainy [Roadmap for reforming higher education in Ukraine] (2018). <dt.ua > EDUCATION > dorozhnya-karta-ref >. [in Ukrainian].

3. Nikolaiev, Ye.B. (2017). Vyshcha osvita v Ukraini: poriadok dennyi dlia reform [Higher education in Ukraine: an agenda for reform]. <http://www.kas.de/wf/doc/kas_49177-1522-13-30.pdf?170612141803>. [in Ukrainian]. 